\title{
ディスクブレーキの鳴きに及ぼす摩擦接触部の動剛性の影響*
}

\author{
大浦靖 典*1, 栗田 裕*2, 松村雄 一*3
}

\section{Influence of Dynamic Stiffness in Contact Region on Disk Brake Squeal}

\author{
Yasunori OURA*4, Yutaka KURITA and Yuichi MATSUMURA \\ ${ }^{* 4}$ Department of Mechanical Systems Engineering, University of Shiga Prefecture, \\ 2500 Hassaka-cho, Hikone-shi, Shiga, 522-8533 Japan
}

\begin{abstract}
This study examines the influence of dynamic stiffness in the contact region on disk brake squeal. The frequency of squeal becomes higher as the thrust pressure grows larger. We think the cause of this phenomenon is that the stiffness of the pad depends on thrust pressure, because the vibration characteristics of the disk and the caliper are not change by thrust pressure. Therefore, we measure the contact stiffness of the pad. The results show that the stiffness of the pad has pressure dependency. To clarify the influence of the pad stiffness on squeal, we analyze the disk-pad-caliper system as the surface contact analysis model, which combines the disk with the pad-caliper by distributed springs.
\end{abstract}

Key Words : Self-Excited Vibration, Frictional Vibration, Modeling, Disk Brake, Squeal, Dynamic Stiffness

\section{1. 緒}

ディスクブレーキに発生する鳴きは，静肃性の観点 から商品価值を低下させるため, ディスクの形状やパ ッドの材質の変更, キャリパヘの減衰の付加など様々 な鳴き対策が行われている，鳴きを効率よく抑制する ために，鳴き発生のメカニズムを解明しようとする試 みは古くから行われてきた (1)(2). 近年では, 従来の鳴き 対策で注目されていたディスクやパッド・キャリパの 振動特性だけではなく, 摩擦接触部の岡性の大きさ ${ }^{(3)}$ や真実接触面積の広さ ${ }^{(4)}$ が鳴きに影響をもつとする報 告がなされている.

著者らは，実際のディスクブレーキの代わりに，構 造が簡単な装置を用いて, 鳴き発生時の振動現象を検 討してきた(5). その結果, 発生する鳴きには, パッド をディスクに押付ける圧力が大きくなるほど周波数が 高くなる押付圧依存性があることが明らかとなった. しかし，ディスクとパッド・キャリパ単体の振動特性

\footnotetext{
* 原稿受付 2007 年 3 月 19 日.

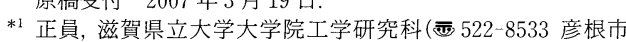
八坂町 2500).

*2 正員, フェロー, 滋賀県立大学工学部.

*3 正員, 滋賀県立大学工学部.

E-mail : n21yooura@usp.ac.jp
}

は，押付圧によって変化しないため，鳴きの押付圧依 存性の要因とはならない.

鳴きの周波数が押付圧に依存する原因は，摩擦接触 部の岡性が押付圧によって変化するためではないかと 考えた，そこで，接触部の剛性を分布ばねで表した面 接触モデルを作成し，接触部の剛性の大きさと鳴きの 関係を考察した ${ }^{(6)}$. 面接触モデルにおいて，接触面内 の剛性をすべて同じ值として解析を行うと, 鳴きが発 生しない解析結果が得られた. 次に, 接触部の剛性に 押付圧依存性をもたせ，接触面内の圧力分布を考慮し て解析を行うと鳴きが発生した。 この鳴きは, 接触部 の剛性が大きいほど周波数が高くなる押付圧依存性を もっていた. 解析より, 摩擦接触部の圧力の分布と接 触部の岡性の押付圧依存性が鳴きの発生に関係がある という知見を得た.

本研究では, ディスク・パッド間の摩擦接触部の剛 性を測定し，剛性の違いが鳴きに与える影響を明らか にする．まず，特性が異なる 2 種類のパッドを用いて 鳴きを発生させる実験を行い，パッドの種類と鳴きの 関倸を調べる. 次に，鳴き実験に用いたパッドの摩擦 接触部の動剛性を，押付荷重を変えて測定する. さら に，測定した動岡性の值を用いて，面接触モデルの解 析を行い, 摩擦接触部の動剛性と鳴き発生の関係につ いて考察する. 


\section{2. 虽き実 験}

$2 \cdot 1$ 偊き試験機 実際のディスクブレーキの代 わりに構造が簡単な模擬的な装置を用いて, パッドの 種類と鳴きの関係を調べた. 実験に用いたディスクの 形状を図 1(a)に示す. ブレーキディスクを内周固定・ 外周自由の境界条件を満たす鋼製の円板で模擬した. 外周部の厚さは $h=6 \mathrm{~mm}$ とした. パッド・キャリパの 形状を図 1(b)に示す. パッドは自動車用のものを $20 \mathrm{~mm} \times 20 \mathrm{~mm}$ に切り抜いて使用した. 同じ寸法のパ ッド・キャリパを用いても, パッドの種類によって発 生する鳴きが異なる現象を調べるため, 鳴きやすいと される試作品のパッド A と実用品のパッド B を用意 した. 摩擦係数 $\mu$ はどちらのパッドも約 0.3 である. キャリパは長さ $80 \mathrm{~mm}$, 幅 $20 \mathrm{~mm}$, 厚さ $t=0.5,1.0$, $1.5,2.0 \mathrm{~mm}$ の鋼製の板ばねで模擬した. 使用する板 ばねの厚さによって，パッドの支持剛性を変えること ができる.

一定の回転数 $40 \mathrm{rpm}$ で回転するディスクの半径 $110 \mathrm{~mm}$ の円周上にパッドを押付け, 摩擦接触部を連 続スリップ状態にして定常的な鳴きを発生させた. 鳴 き音を, ディスクの軸心に対して $45^{\circ}$ の方向に $40 \mathrm{~cm}$ 離して設置した精密騒音計で測定し, 周波数分 析した。

$2 \cdot 2$ 峦きの押付圧依存性 パッドの種類の違い が鳴きに与える影響を, 支持剛性と押付圧を変化させ て調べた. 図 2 に, パッドを支持する板ばねの厚さ $t$ が $0.5,1.0,1.5,2.0 \mathrm{~mm}$ のときに発生した鳴きの周波数 と音圧レベルを示す．横軸の押付圧は，パッドにかけ た押付力を接触面積 $400 \mathrm{~mm}^{2}$ で除した摩擦接触面内の 平均的な值である.

図 2(a)に，パッドA を用いたときに発生した鳴きの

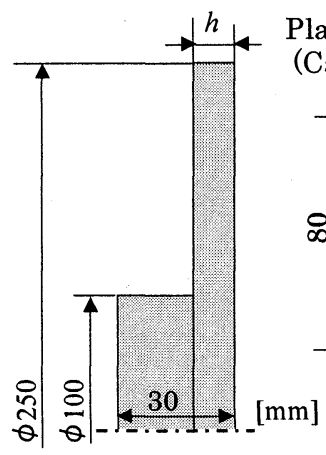

(a) Disk
Plate spring (Caliper)

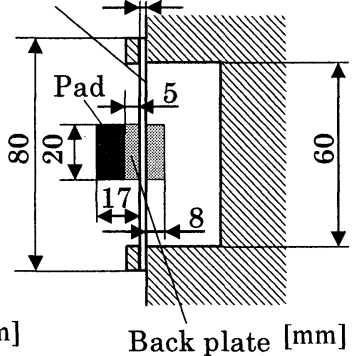

(b) Pad-caliper
Fig. 1 Shape of specimen
音圧と周波数を示す. 板ばね厚さ $t=0.5,1.0 \mathrm{~mm}$ のと きは，押付圧を大きくしていくと，鳴き周波数が $1300 \mathrm{~Hz}$ (図中 $\mathbf{\Delta}$ ) から $2032 \mathrm{~Hz}$ (図中○) に切り換わ ることがわかる.また, $t=1.5 \mathrm{~mm}$ のときは, $2032 \mathrm{~Hz}$ から $3024 \mathrm{~Hz}$ (図中回) に切り換わる. $t=2.0 \mathrm{~mm}$ のと きは，測定した押付圧の範囲では周波数が $3024 \mathrm{~Hz}$ の 鳴きのみが発生する，パッド A を用いたときは，支持 岡性と押付圧が大きいほど高い周波数の鳴きが発生す ることがわかる.

図 2(b)に, パッドBを用いたときに発生した鳴きの音圧 と周波数を示す. $t=0.5,1.0,1.5 \mathrm{~mm}$ のとき, 発生する鳴 きの周波数はすべて $2056 \mathrm{~Hz}$ となった. ただし, $t=0.5,1.0 \mathrm{~mm}$ のときは, 実験した押付圧のほぼ全域で鳴き が発生したが, $t=1.5 \mathrm{~mm}$ のときは，限られた押付圧の範囲 でのみ鳴きが発生した. $t=2.0 \mathrm{~mm}$ のときは, 実験した押付 圧の範用では，鳴きが発生しなかった。

図 2 から，ディスクとキャリパの振動特性が同じでも， 使用するパッドの種類によって，鳴きの周波数や音圧，発 生する押付圧の範井が異なることがわかる.
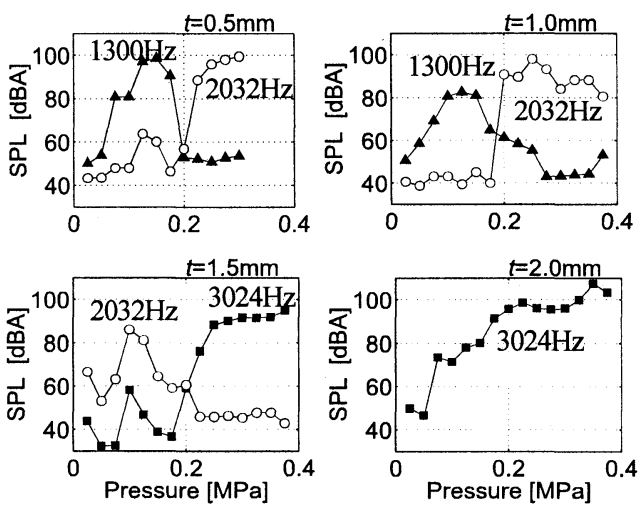

(a) $\operatorname{Pad} \mathrm{A}$
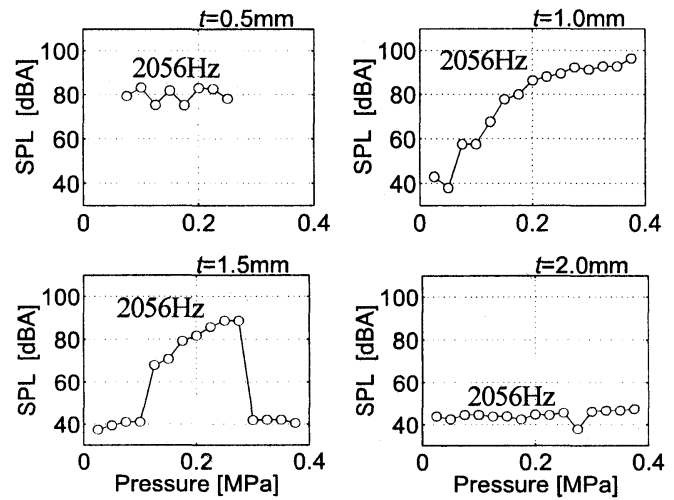

(b) Pad B

Fig. 2 Thrust pressure versus sound pressure level 


\section{3. 犘擦接触部の動剛性の測定}

3-1 動棡性測定原理 パッドによって発生する 鳴きが異なる原因として, 摩擦接触部の動岡性の違い に着目した. 鳴き発生時, 摩擦接触部にはパッドを押 付けることで生じる定常的な圧力と鳴き振動による圧 力の変動が生じている. そこで，一定の押付圧を与え たパッドを，鳴きが発生する周波数帯域のランダム， イズで加振し, 接触部に生じる変位から加振力までの 伝達関数（動剛性）を測定する.

加振によって摩擦接触部に生じる圧力の変動 $f$ を接 触部の岡性 $k$ と減衰 $c$ で表す. 加振によって接触部に 生じる変位を $x$ とすると，

$$
f=k x+c \dot{x}
$$

ラプラス変換して，変位から力までの伝達関数（動剛 性）を求めると,

$$
\frac{F}{X}=k+c s=k\left(1+\frac{c}{k} s\right)
$$

図 3 に式(2)の伝達関数のボード線図を示す. 式(2) の伝達関数は, 大きさ $k$ の比例要素と, 時定数が $T=c / k$ の 1 次進み要素の積と見なせる.よって, 折点 周波数の 10 分の 1 以下の周波数ではゲインがほぼ平坦 となり, 位相進みも $5.7^{\circ}$ 以下となる.このときのゲイ ンの大きさは接触部の剛性 $k$ と見なせる. この $k$ と折 点周波数 $1 / T$ から接触部の減衰 $c$ を求めることができ る.

3-2 䣦甽性測定装置動岡性測定装置の構成 と外観を図 4 に示す．鳴き実験に用いたパッドを本体 基部と加振板で挟み，接触部を加振して動剛性を測定 する. 加振板と駆動源，駆動源の基部は本体加ら独立 しており, 装置上部の推力ねじを締め付けることで, 接触部に任意の押付圧を与えることができる．接触部 の振動を直接測定することはできないので，加振板に

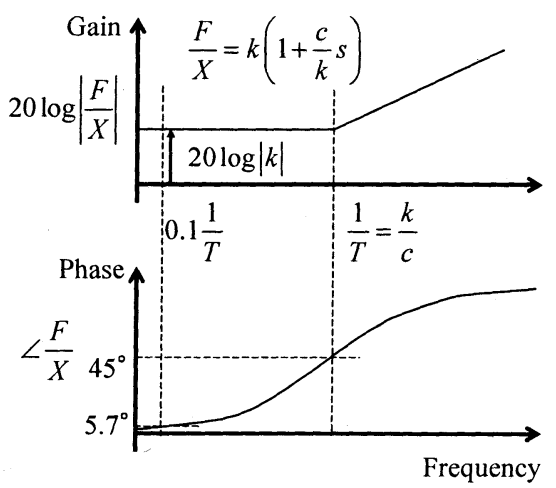

Fig. 3 Measurement principle
生じる変位を接触部に生じる変位 $x$, 本体基部に伝わ る圧力変動をパッドへの加振力 $f$ とみな. 装置本体 の振動特性が測定に影響を及ぼさないよう，十分剛に なるように設計した.

接触部の加振に用いる駆動源には，測定時にパッド にかける押付力に打ち勝つだけの発生力と鳴き周波数 で加振できる高い応答性が求められる．そこで，条件 を満たす駆動源として積層圧電アクチュエータ（NEC TOKIN，AE0505D16）を用いた. 最大発生力 850N, 忘答性 $20 \mathrm{kHz}$ 以上の本アクチュエータを 4 個, 加振板 の四隅に設置することで安定性と十分な発生力を確保 した.

加振によって接触部に生じる変位は，高周波かつ微 小なので, 加速度ピックアップ(Brüel\&Kjær, Type 4393）を加振板に設置して加速度として測定した. 加速度ピックアップの測定周波数帯域は $0.1 \mathrm{~Hz}$ から $16.5 \mathrm{kHz}$ であり，鳴きが発生する周波数帯域での振動 を測定することができる.

接触部への加振力は動的かつ微小であるため, 水晶 圧電式力センサ (KISTLER, 9051A) を用いて测定した. 測定対象のパッドを支える構成になるので，接触部に 生じる変位の測定に影響を及ぼさないために，測定対 象よりも十分に高い岡性をもつ必要がある. 本センサ の測定方向の剛性 $k^{\prime}$ は $9 \times 10^{9} \mathrm{~N} / \mathrm{m}$ であり, 測定される パッドの剛性の 10 倍以上である. また, 準静的な測定 にも十分な精度をもつので，パッドに加える押付圧の 測定にも用いることができる。

$3 \cdot 3$ 測定結果 パッドの摩擦接触部の動岡性の 周波数依存性と押付圧依存性を調べた。パッド $\mathrm{A} の$ 測 定結果を図 5(a)に, パッド B の測定結果を図 5(b)に示 す.上段は測定した伝達関数のゲインを単位面積あた りの動剛性に直したもの，下段は位相を表す．接触部 への加振指令は，実験で発生した鳴き周波数帯域を考

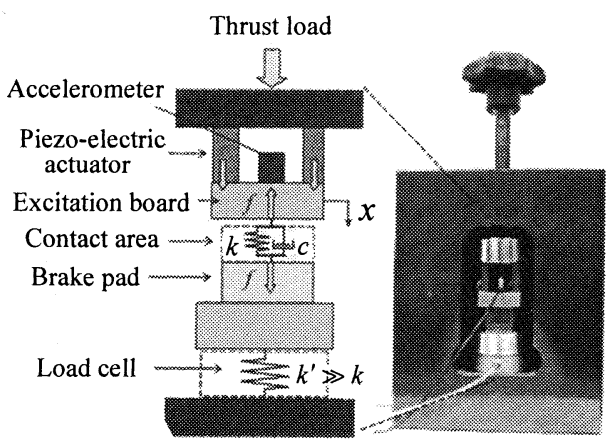

Fig. 4 Experimental apparatus 
慮して, $0 \sim 4 \mathrm{kHz}$ のランダムノイズで行った. 指令 振幅の大きさは，接触部に生じる変位の振幅が $\pm 1 \mu \mathrm{m}$ となるように調整した. パッドへの押付力は，接触部 の面圧が鳴き実験を行った $0.25 \mathrm{MPa}$ から実車制動時の 接触面圧に近い $2.5 \mathrm{MPa}$ までとなるように与えた.

接触部の動剛性の周波数依存性を検討する. 図 5 よ り，測定した周波数帯域の動剛性の大きさは，パッド $\mathrm{A}$ とパッド B の両方とも，ほぼ平坦となっており，位 相進みも $5.7^{\circ}$ 以下であることがわかる. よって，実験 で鳴きが発生した周波数帯域での, 接触部の動剛性 $F / X$ の大きさは接触部の剛性 $k$ とみなせる．また，折点周 波数は測定を行った周波数の 10 倍以上と考えられる. 接触部の減衰 $c$ が鳴きに及ぼす影響は剛性 $k$ に比べて 無視できるほど小さいとみなせる.

また，接触部の動剛性には押付圧依存性があること がわかる. パッド $\mathrm{A}$ とパッド $\mathrm{B}$ の動剛性の大きさと押 付圧依存性の違いが鳴きに与える影響を考察する必要 がある.
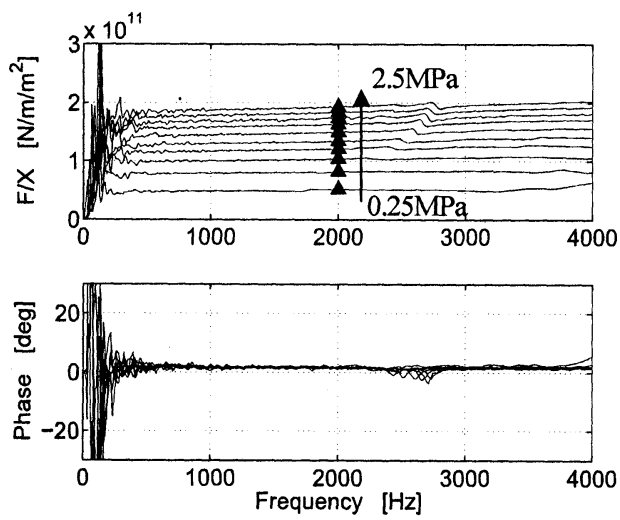

(a) $\mathrm{Pad} \mathrm{A}$
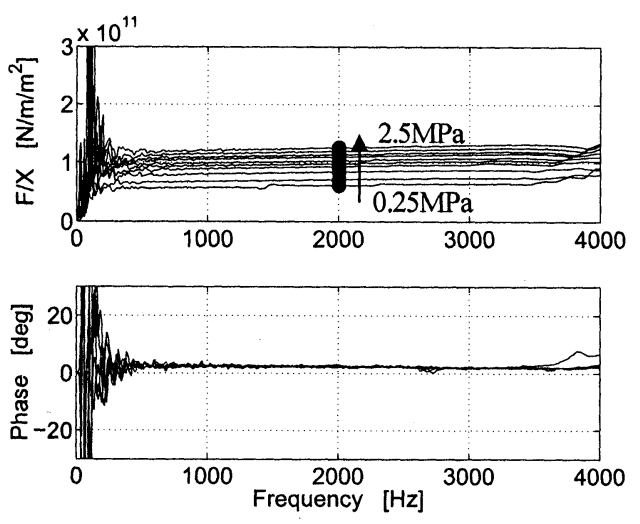

(b) Pad B

Fig. 5 Frequency dependency of dynamic stiffness
3 -4 摩㨲接触部の㣚性の押付圧依存性接触部 の剛性と押付圧の関係を近似式で表し, パッドの剛性 がもつ押付圧依存性を評価する. 接触部の剛性の測定 值と押付圧の関係を図6に示寸．図中の剛性の值は, 鳴き実験において発生しやすかった鳴きの周波数に近 い $2 \mathrm{kHz}$ での動剛性の大きさを用いた．パッド $\mathrm{A}$ の測 定值が図 5(a)に示したム，パッドBが図 5(b)に示した に対応する. 図6から，押付圧が小さいときはパッ ドAの剛性がパッド Bよりも小さいことがわかる.し かし，押付圧が大きくなったときの剛性の増加量はパ ッド $\mathrm{A} の$ 方が大きいため, 最終的にはパッド $\mathrm{A}$ の剛性 がパッドBよりも大きくなっている. そこで，押付圧 $p$ と接触部の剛性 $k$ の関係を，剛性の大きさを表す係 数 $K_{N}$ と押付圧依存性の程度を表す非線形性指数 $N$ を 用いて次式で表す。

$$
k=K_{N} p^{N}
$$

押付圧が 0 のときの岡性は，押付圧が大きいときの凬性に 比べて十分し小さい值であると考え，0 とした，接䖵の剛 性の押付圧依存性が大きいパッドほど, 非線形性指数 $N$ が 大きくなる. 非線形性指数 $N か ゙$ 同じ場合, 剛性の大きいッ゚ ッドほど $K_{N}$ が大きくなる.

図 6 に, パッド $\mathrm{A}$ とパッド $\mathrm{B}$ の接触部の剛性の近似を 非線形性指数 $N$ の值を变えて行った結果を実線で示す．押

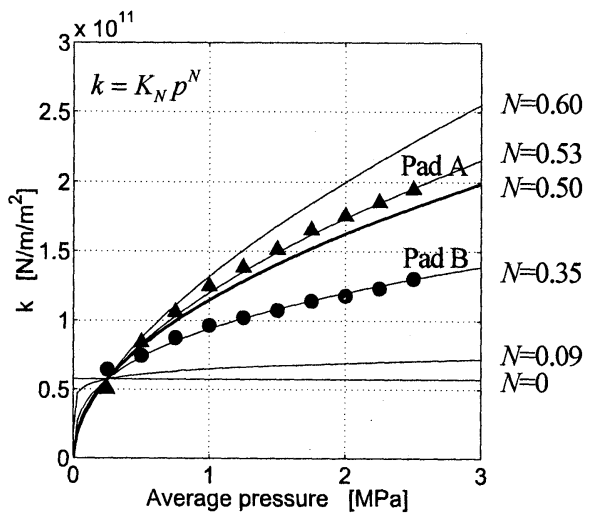

Fig. 6 Pressure dependency of contact stiffness

Table 1 Nonlinearity of pad stiffness

\begin{tabular}{|c|c|c|c|c|}
\hline$N$ & $K_{N}$ & $n$ & $k_{n}$ & Remarks \\
\hline 0 & $5.75 \times 10^{10}$ & 1.00 & $5.75 \times 10^{10}$ & \\
\hline 0.09 & $1.86 \times 10^{10}$ & 1.10 & $1.78 \times 10^{11}$ & \\
\hline 0.35 & $6.98 \times 10^{8}$ & 1.55 & $2.59 \times 10^{13}$ & Pad B \\
\hline 0.50 & $1.15 \times 10^{8}$ & 2.00 & $3.30 \times 10^{15}$ & \\
\hline 0.53 & $7.68 \times 10^{7}$ & 2.14 & $1.45 \times 10^{16}$ & Pad A \\
\hline 0.60 & $3.32 \times 10^{7}$ & 2.50 & $6.41 \times 10^{17}$ & \\
\hline
\end{tabular}


付圧が $0.25 \mathrm{MPa}$ のとき,パッド $\mathrm{A}$ とパッドB の剛性が近い

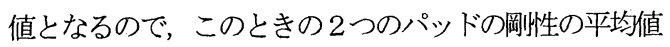
$5.75 \times 10^{10} \mathrm{~N} / \mathrm{m}^{\mathrm{m}} \mathrm{m}^{2}$ を近似線が通るように $K_{N}$ の值を定めた。 表 1 に近似線に用いた $N$ と $K_{N}$ O值を示寸。 パッド A は $N=0.53$, パッド $\mathrm{B} は N=0.35$ とすると, 近让式は実験の剛 性值を表すことができる. 発生する鳴きの周波数が変化し やすいパッドAは,パッドBに比へて非線形性指数 $N$ が大 きく，押付圧によって接触部の岡性が変化しや扵いことが わかる.

\section{4. 面接触モデルによる解析}

4・1 面接触モデル 前報(6)で作成した面接触モ デルを用いて，接触部の剛性の押付圧依存性が鳴きに 与える影響を考察する. 図 7 に, ディスクを並進の 1 自由度, パッドを並進と回転の 2 自由度をもつ振動 系で表した面接触モデルを示す。摩擦接触部の剛性は 分布ばねで表している. ディスクの並進運動の運動方 程式は, 次式となる.

$$
M \ddot{x}_{d}=-K x_{d}-\int f d A
$$

パッド・キャリパの並進運動の運動方程式は,

$$
m \ddot{x}_{p}=-k_{t} x_{p}+\int f d A
$$

パッド・キャリパの回転運動の運動方程式は,

$$
J \ddot{\varphi}=-k_{\varphi} \varphi+\int \mu f \ell_{G} d A+\int f l d A
$$

接触部に生じる鳴き振動による圧力の変動 $f$ は, 接触 部の剛性 $k$ と接触部に生じるディスクとパッドの鳴き 振動による相対変位 $x$ を用いて表す。

$$
f(l)=k x=k\left(x_{d}-x_{p}-l \varphi\right)
$$

ここで, lは接触面内鉛直方向の位置を表す. 式(7)を 運動方程式に代入し, 特性方程式を導出すると, $s^{2}$ に ついて 3 次式 (sについての6 次式) となる.この 特性方程式が共役複素根 $s=X \pm i Y$ をもち，その実部 $X$ が正となるとき, 系は不安定となり, 自励振動が発 生する. 根の実部の大きさ $X$ は, 不安定の程度を表し ているので, 鳴きやすさと呼ぶ. 根の虚部の大きさ $Y$ は鳴きの周波数を表す.

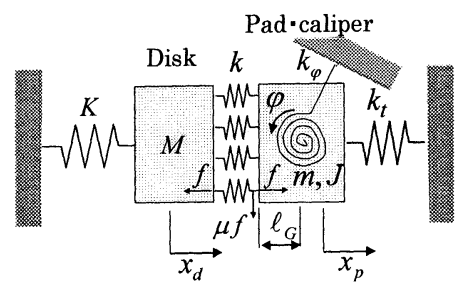

Fig. 7 Surface contact analysis model
$4 \cdot 2$ 接触部の制性 測定した接触部の剛性を用 いて面接触モデルの解析を行う, 鳴き発生時, 接触部 には押付力による定常的な押付圧 $p$ と鳴き振動による

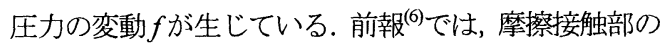
圧力と変位の関係を次式で表した。

$$
p+f=k_{1}\left(x_{0}+x\right)+k_{2}\left(x_{0}+x\right)^{2}
$$

ここで， $x_{0}$ は押付圧によって接触部に生じる定常的な 変形量である. $x$ は鳴き振動によって接触部に生じる ディスクとパッドの相対変位の変動を表す.また, 接 触部の圧力と剛性の関係は次式とした.

$$
k=\sqrt{k_{1}^{2}+4 k_{2} p}
$$

式(9)を用いると接触部の剛性 $k$ は押付圧が 0 のとき $k_{1}$ となる. また， $k_{2}$ の值に応じて押付圧 $p$ の 2 分の 1 乗 の割合で岡性が大きくなる.この押付圧依存性は, 図. 6 の非線形性指数 $N=0.5$ の場合に相当する. 図6から, 式(9)を用いて接触部の剛性の押付圧依存性を表した 場合, $k_{1}, k_{2}$ に適切な值を与えることでパッド $\mathrm{A}$ の剛 性の押付圧依存性は表せるが, パッド B の剛性の押付 圧依存性を表せないことがわかる。

面接触モデルを，パッドごとに異なる剛性の非線形 性を表すことができるように，発展させる，摩擦接触 部の圧力と変位の関係を次式で表す.

$$
p+f=k_{n}\left(x_{0}+x\right)^{n}
$$

ここで, $n$ は接触部に生じる変位と押付圧の関係の非 線形性を表す． $k_{n}$ は剛性の大きさを表す係数である. 押付圧が 0 のときの岡性は，押付圧が大きいときの剛 性に比べて十分に小さい值であると考え 0 とした. 二項定理を用いて, 式(10)を展開すると, 押付圧 $p$ は 次式で表される.

$$
p=k_{n} x_{0}^{n}
$$

また, 接触部に生じる鳴き振動 $x$ による圧力変動 $f$ は 次式で表される. ただし， $x$ の高次項は微小であるた め無視する.

$$
f=n k_{n} x_{0}^{n-1} x
$$

式(12)の $x$ にかかっている係数を，接触部の岡性 $k$ とみなす. 式(11)を用いて $k$ から $x_{0}$ を消去すると, 接触部の岡性と押付 圧の関係式となる。

$$
k=n k_{n}^{\frac{1}{n}} p^{\frac{n-1}{n}}
$$

この式(13)と，実験での接触部の剛性と押付圧の関係の近似 式である式(3)を比較すると次の関係が成り立つ.

$$
N=\frac{n-1}{n}, K_{N}=n k_{n}^{\frac{1}{n}}
$$

表 1 に $N$ と $K_{N}$ に対応する $n$ と $k_{n}$ の值を示す. この接 触部の剛性を表す值と式(12)を運動方程式に代入する ことで, 安定判別ができる. 安定判別法や鳴きが発生 
する条件については前報(の)の面接触モデルの解析と同 じになる.

4・3 解析結果 測定した接触部の岡性を用いて, 面接触モデルの解析を行った. 図 8(a)にパッド A の, 図 8(b)にパッドBの接触部の剛性を用いた解析結果を 示寸. 鳴きの発生に影響をもつディスクの固有振動数 $f_{d}$ を縦軸, パッド・キャリパ単体の回転方向の固有振 動数 $f_{\varphi}$ を横軸にとった. 図中の破線は板厚 $h=6 \mathrm{~mm} の$ ディスクの固有振動数と, 板ばね厚さ $t=0.5,1.0,1.5$, $2.0 \mathrm{~mm}$ のパッド・キャリパ単体での回転方向の固有振 動数を表している. 破線の交点の○は押付力が $50 \mathrm{~N}$ (平 均押付圧 $0.125 \mathrm{MPa}), \times$ は $100 \mathrm{~N}(0.25 \mathrm{MPa}), \triangle$ は $150 \mathrm{~N}(0.375 \mathrm{MPa})$ のときに実験で鳴きが発生した固有 振動数の組合せである. 図中の実線の内側が鳴きやす さ $X$ が正の值となる鳴き発生範囲であり, このときの 鳴き周波数 $Y$ はディスクの固有振動数 $f_{d}$ に近い值とな っている. 細い実線の内側が接触面内の平均押付圧を $0.125 \mathrm{MPa}$ としたときの鳴き発生範囲, 太い実線の内側 が平均押付圧を $0.375 \mathrm{MPa}$ としたときの鳴き発生範囲 である。

図 8(a)より, パッドA の鳴き発生範囲は, 右上がり となっており, パッド・キャリパの回転方向の固有振 動数が大きいほど, 高い周波数の鳴きが発生しやすい ことを示している，また，押付圧が大きくなると鳴き 発生範囲が上方向に移動する. この解析結果は, 実験 において支持剛性や押付圧が大きいと高い周波数の鳴 きが発生することに対応する.

図 8(b)より, パッドB の鳴き発生範囲は右上がりの 傾向が, $f_{\varphi}$ が小さいときにパッドAに比べて緩和され ていることがわかる.これは，パッドの支持剛性を変 更しても鳴き周波数が変化しにくいことを表している. パッドBを用いた鳴き実験において $2 \mathrm{kHz}$ 付近の周波 数の鳴きのみが発生したことに対応する. ただし, 実 験では $t=2.0 \mathrm{~mm}$ のときは鳴き自体が発生しなかった が，解析では $3 \mathrm{kHz}$ 付近の鳴きが発生する結果となっ ている.

接触部の剛性の非線形性と鳴きの発生しやすさの関 係を検討する. 鳴き実験において, 非線形性指数が大 きいパッド $\mathrm{A}$ は常に鳴きが発生していたが, 非線形性 指数が小さいパッドBは鳴きが発生しない押付圧や支 持剛性が存在していた. 非線形性指数が小さいときに 鳴きが発生しにくくなる可能性について, 面接触モデ ルを用いて考察した. 図 8(c)に, 非線形性指数を $n=1.1$ と小さくしたときの鳴き発生範囲を示す. パッドAと パッド B の鳴き発生範囲と比べると, 全体的に狭くな っていることがわかる. また，押付圧が変化したとき

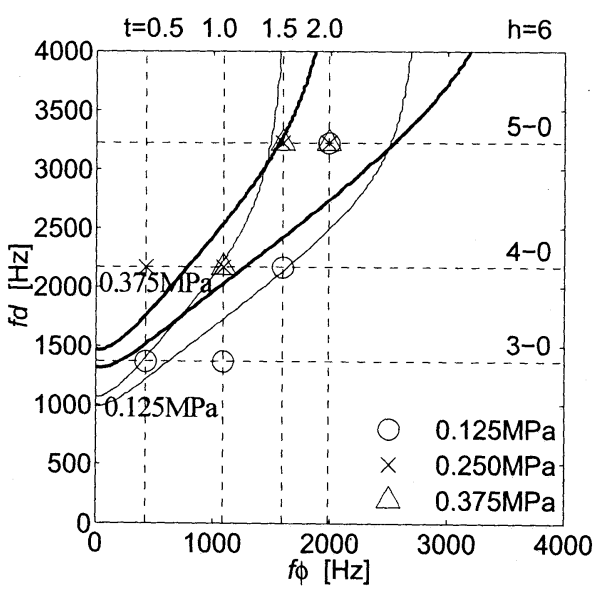

(a) $n=2.14(\operatorname{Pad} \mathrm{A})$

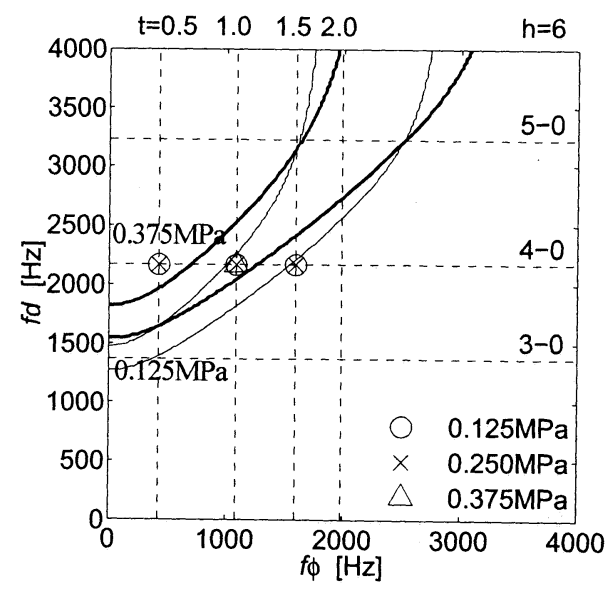

(b) $n=1.55(\mathrm{PadB})$

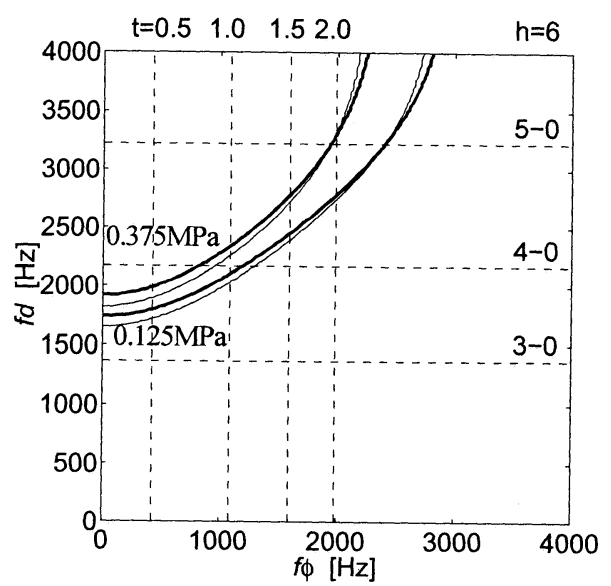

(c) $n=1.10$

Fig. 8 Instability area 
の鳴き発生範囲の移動量も少なくなっている.さらに 非線形性を小さくして解析を行うと，鳴き発生範囲が 細くなっていき, $n=1$ のときには鳴き発生範囲がなく なった. 非線形性が小さいパッドを用いると, 鳴きが 発生する押付圧ごとの $f_{d}$ と $f_{\varphi}$ の組み合わせが限られて くるため，使用するディスクとパッド・キャリパのも つ固有振動数によっては, 鳴きが発生しない場合があ る.

図 8 から，ある押付圧で同じ程度の大きさの剛性を もったパッドでも，剛性の押付圧依存性（非線形性指 数）が異なると, 発生しやすい鳴きの周波数が変わる ことがわかる. また，剛性の押付圧依存性が大きいパ ッドは，鳴きが発生する $f_{d}$ と $f_{\varphi}$ の組み合わせの幅（鳴 き発生範囲)が広くなり, 押付圧による変化も大きい. このため, 接触部の岡性の押付圧依存性が大きいパッ ドAは, パッドの支持剛性や押付圧を変えた際に, 発 生する鳴き周波数が移り変わりやすい.

\section{5. 結 論}

ディスクブレーキに発生する鳴きの周波数や音圧が 使用するパッドや押付圧によって変化する現象を解明 するため, 摩擦接触部の岡性の押付圧依存性に着目し た. 測定した接触部の剛性を用いて面接触モデルの解 析を行い, 剛性の押付圧依存性の違いが鳴きに与える 影響を考察した. 本研究で得られた結果を, 以下にま とめる.

（1）ディスクとパッドの摩擦接触部の動剛性は, 周 波数依存性がなく，剛性が支配的である.

（2）摩擦接触部の剛性の大きさと押付圧依存性はパ ッドによって異なる.

（3）接触部の剛性の押付圧依存性によって, 発生し やすい鳴きの周波数が異なる.

(4) 接触部の剛性の押付圧依存性が大きいパッドは, パッドの支持剛性や押付圧によって発生する 鳴きの周波数が変化しやすい.

\section{謝辞}

本研究を進めるにあたって，西澤幸男氏をはじめと する株式会社アドヴィックスの方々には実験用ブレー キパッドの試作や実際のブレーキでの知見に基づいた モデル解析への御助言など多大な御支援を頂いた. こ こに記して謝意を表す。

\section{文献}

(1) Earles, S.W.E. and Lee, C.K., Instabilities Arising from the Frictional Interaction of a Pin-Disc System Resulting in Noise Generation, Trans. ASME, H. Eng. Ind. , 98-1, (1976), 81-86.

(2) Millner, N., An Analysis of Disk Brake Squeal, SAE Paper, 780332 (1978).

(3) Sueoka, A .Ryu, T. and Shirozu, K. , Squeal of a Disk Brake of Floating Type for Cars: Ist Report, Relationship between Occurrence of Squeal and Contact Region between Rotor and Pads in Experiment, Transactions of the Japan Society of Mechanical Engineers. Series C, Vol. 67, No.658 (2001), pp. 1719-1726.

(4) Mikael, E., Staffan, J., Tribological surfaces of organic brake pads, Tribology International, 33 (2000), pp.817-827.

(5) Kurita, Y., Matsumura ,Y., Ito ,A. ,Tamura ,T. and Oura, Y., Squeal Vibration in Disk Brake, Transactions of the Japan Society of Mechanical Engineers, Series C, Vol.70, No.694 (2004), pp.1609-1615.

(6) Oura, Y., Kurita, Y., Matsumura, Y.and ,Tamura ,T., Surface Contact Analysis Model for Squeal on Disk Brake, Transactions of the Japan Society of Mechanical Engineers, Series C, Vol. 73, No. 731 (2007), pp. 1977-1984. 